\title{
HISTORICAL INDIGENOUS PEOPLES' LAND CLAIMS: A COMPARATIVE AND INTERNATIONAL APPROACH TO THE COMMON LAW DOCTRINE ON INDIGENOUS TITLE
}

\author{
JÉRÉMIE GILBERT*
}

\begin{abstract}
Within common law systems a body of jurisprudence has developed according to which indigenous peoples' land rights have been recognized based upon historical patterns of use and occupancy and corresponding traditional land tenure. Looking at the emerging common law doctrine on aboriginal or native title, this article examines how legal institutions are building a theory on historical land claims through the recognition of indigenous laws deriving from prior occupation. The article analyses how the common law doctrine builds a bridge between past events and contemporary land claims. The aim of this article is to examine to what extent the common law doctrine proposes a potential model for the development of a legal theory on the issue of indigenous peoples' historical land claims. In doing so the article analyses how the common law doctrine compares with international law when dealing with historical arguments by focusing on issues of intertemporal law and extinguishment.
\end{abstract}

\section{INTRODUCTION}

Since the adoption of the 1989 International Labour Organization Convention 169 on the Rights of Indigenous and Tribal Peoples (ILO 169), ${ }^{1}$ there has been a growing focus on the rights of indigenous peoples under international law in the past decades. The United Nations (UN) declared the decade 1994-2004 as the first World Decade on the Rights of Indigenous Peoples, and 2005-2015 as the second decade. ${ }^{2}$ In 2002, the Permanent Forum on Indigenous Issues was established as an advisory body to the UN Economic and Social Council. ${ }^{3}$ In June 2006, the recently established Human Rights Council adopted the text of the UN Declaration on the Rights of Indigenous Peoples, for which adoption

* Lecturer, Transitional Justice Institute, University of Ulster. An abridged version of this article has been presented by the author at the 2005 Commonwealth Law Conference in London, on which the idea of this article was developed. The author wishes to thank Christine Bell, Joshua Costellino and David Keane for comments on earlier drafts of this work.

1 Convention Concerning Indigenous and Tribal Peoples in Independent Countries (ILO No 169), reprinted in ILM 1382 (1989). Only two Commonwealth countries - Fiji and Dominicahave ratified the Convention.

2 See General Assembly Resolution A/RES/48/163 (1994) and Resolution A/RES/59/174 (2005).

3 Economic and Social Council Resolution 2000/22. 
currently lies with the UN General Assembly. ${ }^{4}$ More generally, the rights of indigenous peoples have generated an expanding jurisprudence from the UN treaty monitoring bodies such as the Human Rights Committee or the Committee on the Elimination of Racial Discrimination. ${ }^{5}$ Land rights have been at the heart of indigenous peoples' claims under international law. ${ }^{6}$ While a profound relationship with lands and territories characterizes indigenous groups, indigenous peoples have been and are repeatedly deprived of their lands. ${ }^{7}$ Consequently, one common claim of indigenous peoples under international law is the claim for the recognition of their right to ownership and control over their territories.

Indigenous peoples have often been the victims of dispossession that took place in the past. The question of land rights is often an issue of restoring lands that were taken under a past discriminatory enterprise and linked to a continuing denial of indigenous peoples' rights. Moreover, indigenous peoples' rights to their lands derive from traditional occupation and indigenous laws and customs relating to land ownership. Hence, the issue of land rights for indigenous peoples is entrenched with historical elements, and from this perspective international law is dealing with arguments of an historical nature. However, international legal theory is limited when it comes to dealing with historical injustices. ${ }^{8}$ The question of historical human rights violations and reparations for past wrongs is an extremely underdeveloped part of international law. ${ }^{9}$ The weakness of international law in addressing the relationship between historical arguments and contemporary land claims has some adverse consequences on the development of indigenous peoples' rights at the international level. ${ }^{10}$

Regarding indigenous peoples' historical land rights, considerable developments have taken place under the jurisprudence of common law jurisdictions in the last decades. These developments are based on the emergence of a body of law which is referred to as aboriginal or/and native title doctrine, with an expanding literature using notions such as 'native title laws'. ${ }^{11}$ This

\footnotetext{
4 See UN Doc A/HRC/1/L.10 (30 June 2006); and also UN Doc E/CN.4/Sub.2/1994/56.

5 See P Thornberry, Indigenous Peoples and Human Rights (MUP, Manchester, 2002); and J Anaya, Indigenous Peoples in International Law (OUP, Oxford, 2004).

6 See J Gilbert, Indigenous Peoples' Land Rights under International Law: From Victims to Actors (Transnational Publishers, Martinus Nijhoff, Ardsley, 2006)

7 See 'Indigenous Peoples and their relationship to Land: Final working paper prepared by the Special Rapporteur, Erica-Irene A. Daes' UN Doc E/CN.4/SUB.2/2001/21.

8 See E Barkan, The Guilt of Nations, Restitution and Negotiating Historical Injustices (John Hopkins University Press, Baltimore, 2000).

9 See G Ulrich and L Krabbe Boserup (eds), Reparations: Redressing Past Wrongs, Human Rights in Development Yearbook 2001 (Kluwer Law International, The Hague, 2003).

10 The most recent illustration includes the resolution proposed by the Third Committee of the UN General Assembly deferring 'consideration and action on the United Nations Declaration on the Rights of Indigenous Peoples'. See document A/C.3/61/L.57/Rev.1 (28 Nov 2006).

11 G Yunupingu (ed), Our Land is our Life, Land Rights, Past Present and Future (University of Queensland Press, St Lucia, 1997). See also P Patton, 'The Translation of Indigenous Land into Property: The Mere Analogy of English Jurisprudence’ (2000) 6 Parallax 25-38.
} 
movement was mainly developed through the jurisprudence of both the Supreme Court of Canada and the High Court of Australia in the 1990s. ${ }^{12}$ These two jurisdictions have established a legal doctrine labelled as 'aboriginal' (Canada) or 'native' (Australia) title. As this article will examine the reference to a common law doctrine of indigenous peoples' land rights is gradually becoming much more widespread, with national courts from Malaysia, Belize, South Africa, Botswana, or Kenya referring to it. This doctrine recognizes that those customary indigenous laws regarding land ownership which preceded common law, should be recognized as title generating. In doing so the common law doctrine raises fundamental issues about the legal repercussions of the past. The recognition of indigenous peoples' land rights through the doctrine relies on the idea that the colonization of indigenous territories has not completely 'extinguished' indigenous peoples' land rights, as such rights have 'survived' the colonial conquest. Therefore it recognizes indigenous peoples' contemporary land rights based on historical arguments that predated colonization. ${ }^{13}$ The objective of such recognition by national jurisdiction is 'reconciliation' between States and their indigenous populations. ${ }^{14}$

From this perspective the common law doctrine potentially offers an interesting platform for the reconciliation between past dispossession and presentday land claims. While the purpose itself is remarkable at a time when issues of reparation for past wrongs are creating immense debate at the international level, ${ }^{15}$ the doctrine raises some difficult issues regarding the development of a legal framework on the interaction between historical wrongs and presentday land claims. The present article engages this particular issue by comparing the common law doctrine on indigenous peoples' land rights with international legal developments.

In exploring the relationship between the common law doctrine and international law the article wishes to analyse whether the common law doctrine could be seen as an enlightened way of developing a legal theory on indigenous peoples' historical land claims. To this purpose, the first part of the article will analyse to what extent the different approaches undertaken by national jurisdictions referring to the common law doctrine present some common

\footnotetext{
12 This is also true for New Zealand. However, the situation remains particular as the recognition of native title is flowing from the existence of the Treaty of Waitangi. See Attorney-General v Ngati Apa [2003] 3 NZLR 643, 2003 NZLR. See also US Supreme Court, Oneida Indian Nation $v$ Country of Oneida (1974) 414 US 661. In general, see K McNeil, Common Law Aboriginal Title (OUP, Oxford, 1989).

13 A Reilly and A Genovese, 'Claiming the Past: Historical Understanding in Australian Native Title Jurisprudence (2004) 3 Indigenous Law Journal 19.

14 Looking at Canada, Australia and New Zealand McHugh refers to the emergence of a 'jurisprudence of reconciliation': PG McHugh, Aboriginal Societies and the Common Law (OUP, Oxford, 2004) 539-611. See also K McNeil, 'Reconciliation and the Supreme Court: The Opposing Views of Chief Justices Lamer and McLachlin’ (2003) 2 Indigenous Law Journal 1.

15 See J Miller and R Kumar (eds), Reparations: Interdisciplinary Inquiries (OUP, Oxford, 2007).
} 
features on the issue of historical land claims. Building on this analysis, the second part of the article will examine how the common law doctrine proposes some innovative legal theories on the relationship between historical events and contemporary claims by recognizing indigenous customary systems of law. The third part of the article will contrast the common law notion of extinguishment, which has been developed as a common law 'solution' to deal with the past dispossession of indigenous peoples, to international human rights standards on indigenous peoples' rights. Finally, based on such analysis the conclusion will examine whether the common law doctrine on indigenous peoples' land rights could serve as a potential source for the development of international law on the issue of historical land claims.

\section{TOWARDS A COMPREHENSIVE DOCTRINE: ON 'INDIGENOUS TITLE'}

Indigenous peoples' land claims frequently come before the courts of Canada, Australia or New Zealand, but have been less frequently litigated elsewhere. However, with the recent growth of indigenous organizations in Asia and Africa, we are witnessing the internationalization of indigenous claims. While such developments often are seen only through the lens of national adjudication, the national decisions on indigenous peoples' land rights commonly depend on a high level of comparative analysis. The following discussion examines to what extent such development could indicate the emergence of a comprehensive common law doctrine on indigenous peoples' land rights, first by looking at its geographical scope, and secondly, by analysing what are the common key features of such doctrine within the different national jurisdictions.

\section{A. The emergence of a common jurisprudence on 'indigenous title'}

Regarding indigenous peoples' land rights, national jurisdictions in Australia, Canada and New Zealand have developed a high level of comparative analysis through a common law reference to aboriginal or native title. ${ }^{16}$ Hence, in recent years, when addressing indigenous peoples' land rights, there has been a large focus on the jurisprudence emerging from these three countries. ${ }^{17}$ While the concept originated mainly from the jurisprudence of the High Court of Australia and the Supreme Court of Canada, recent decisions from other national jurisdictions in other Commonwealth countries have referred to the same concept as a common law reference. For example, in a case involving some members of the Orang Asli community in Malaysia, the High Court of Malaysia has recognized that indigenous peoples have specific rights to their

\footnotetext{
16 For references, see McNeil (n 12).

17 P Haveman (ed), Indigenous Peoples Rights in Australia, Canada and New Zealand (OUP, Oxford, 1999).
} 
lands on the basis of the common law doctrine of native title. ${ }^{18}$ Referring to leading cases on aboriginal title from Canada and Australia, the Malaysian High Court affirmed that 'native title' is the right of the natives to live on their land. The judge, Mokhtar Sidin JCA, applied such a right to the indigenous peoples of Malaysia affirming the Orang Asli community's common law right to their lands. The judge stated:

I believe this is a common law right which the natives have and which the Canadian and Australian courts have described as native title. I would agree that in Malaysia the aborigines' common law rights include, inter alia, the right to live on their land as their forefathers had lived and this would mean that even the future generations of the Aboriginal people would be entitled to this right. ${ }^{19}$

In this case, the judge also ruled that aboriginal common law rights coexist with other national statutory rights guaranteeing indigenous peoples' land rights. $^{20}$

Similar references to a common law doctrine on aboriginal or native title have been made by several national jurisdictions. In Kenya, in a case at the High Court, the Ogiek indigenous community has referred to decisions from Australia on native title to argue for their rights to live on their traditional territories. ${ }^{21}$ In a case concerning indigenous peoples' land rights in Belize, that went to the Inter-American Commission of Human Rights, both the State and the concerned indigenous peoples referred to the doctrine of aboriginal title as applicable within the national context of Belize. ${ }^{22}$ The indigenous community notably argued that as a former British colony 'the common law of Belize should be deemed to incorporate the common law doctrine that upholds the property rights of indigenous peoples on the basis of customary land tenure, referred to by common law courts as "aboriginal rights" or "title", ${ }^{23}$ More recently, references to the common law doctrine were also made in Botswana. In December 2006, the High Court of Botswana ruled that the removal of the Basarwa San community living in the Central Kalahari Game Reserve was unlawful. ${ }^{24}$ Access to the reserve was restricted and the indigenous community could no longer enter the land they had lived on and occupied for centuries. This threatened their traditional lifestyle based on hunting and gathering. In this

\footnotetext{
18 See Adong bin Kuwau v Kerajaan Negeri Johor [1997] 1 MLJ 418, [1998] 2 MLJ 158.

19 ibid 430.

20 On this issue see R Bulan, 'Native Title as a Proprietary Right under the Constitution in Peninsula Malaysia: A Step in the Right Direction?' (2001) 9 Asia Pacific Law Review 83.

21 Republic of Kenya - In the High Court of Kenya at Nairobi Civil Case No 238 of 1999 (OS). See also High Court at Nakuru, Moses Lesiamon Ole Mpoe v Commissioner Of Lands [2005].

${ }^{22}$ Maya indigenous community of the Toledo District $v$ Belize, Case 12.053, Report No 40/04, Inter-Am CHR, OEA/Ser.L/V/II.122 Doc 5 rev 1 at 727 (2004) para 107; and see the conclusion of the Commission on this point, para 131.

23 ibid para 48.

24 High Court of Botswana, Roy Sesana and Ke/wa Setlohobogwa v The Attorney General, Misca No 52 of 2002 (13 Dec 2006).
} 
case, the indigenous community notably argued their right to remain on their land based on their pre-existing rights recognized under common law. In its decision, the High Court recognized that the indigenous community was legally in possession of its lands. Interestingly, in reaching such conclusion, one of the three judges, Justice Phumaphi, mentioned several precedents from the Privy Council and the High Court of Australia referring to the common law doctrine on 'native title', which were applicable in Botswana. Similar references to the common law doctrine on aboriginal or native title have been developed in ongoing litigations in Guyana ${ }^{25}$ and Cameroon. ${ }^{26}$

Regarding the propagation of the common law doctrine, another important development took place in South Africa which possesses a pluralistic legal system based on Roman-Dutch law and English common law. ${ }^{27}$ Following the fall of the apartheid regime a crucial issue in South Africa was the question of land restitution, as the previous racist regime was based on discriminatory land distribution. ${ }^{28}$ As a result the post-apartheid government has put in place an important piece of legislation, the Restitution of Land Rights Act 22 of 1994 (which was amended in 1995 and 1996), ${ }^{29}$ dealing with land restitution. In a long legal dispute that was settled in the Constitutional Court of South Africa, the Richtersveld Community, an indigenous community, have been entitled to claim land restitution under this act. ${ }^{30}$ During the proceedings the concerned indigenous community relied on the doctrine of aboriginal title as part of the common law of South Africa. In a primary decision, the Land Claims Court rejected the application of the common law doctrine within South Africa. ${ }^{31}$ In appeal, the Supreme Court of Appeal (SCA) decided that it was "unnecessary to decide whether the doctrine forms part of our common law or whether common law should be developed to recognise Aboriginal rights' ${ }^{32}$ While the majority of the judges refused to enter the debate on whether the aboriginal title doctrine was applicable in South Africa, Vivier ADP relied on the common law doctrine in his finding, and several references to cases dealing with aboriginal/native title were made throughout the judgment. The Court found that the Richtersveld Community's customary right of ownership had

\footnotetext{
25 See the case filed in 1998 by six leaders from the Akawaio and Arecuna communities, for references: L Anselmo and F MacKay, Indigenous Peoples, Land Rights and Mining in the Upper Mazaruni (Global Law Association, Tilburg, 1999).

${ }^{26}$ For references, see The Bakweri Land Claims Committee (BLCC) $v$ The Republic of Cameroon (Case No 260/2002), African Commission on Human and Peoples' Rights.

27 R Zimmermann and D Visser, Southern Cross: Civil Law and Common Law in South Africa (Clarendon Press, Oxford, 1996).

28 See V Jaichand, Restitution of Land Rights: A Workbook (Lex Patria, Johannesburg, 1997).

29 Restitution of Land Rights Act, 1994-Act No 22 [as amended by Act No 84, 1995 and Act No 78, 1996].

30 For an overview of the proceedings, see L Amena Hoq, 'Land Restitution and the Doctrine of Aboriginal Title: Ritchersveld Community v. Alexkor Ltd and Another' (2002) 18 SAJHR 421.

31 For an illustration, see Richtersveld Community $v$ Alexkor Limited and another LCC151/98 (22 March 2001), paras 44-8, 52.

32 The Richtersveld Community v Alexkor Limited and the Government of the Republic of South Africa, Case No 488/2001, Supreme Court of Appeal of South Africa (24 Mar 2003).
} 
survived the annexation by the British Crown, as "these rights constituted a "customary law interest" and consequently a "right in land" ... 33 Thus, even though the doctrine of aboriginal/native title was not 'imported' as such, in this case the concerned indigenous peoples had their right to land recognized based on the exact same core principles on which the common law doctrine on indigenous title is based; namely that the colonization of indigenous territories did not amount to the full extinguishment of their rights, and that courts ought to recognize indigenous customary laws as a source of land title. As Barry highlights: 'the finding of the SCA that the Richtersveld Community held a customary interest at the time of annexation is very much akin to accepting the doctrine of aboriginal or native title'. ${ }^{34}$

The application of the common law doctrine on aboriginal/native title was also raised at the Constitutional Court level. The Constitutional Court pointed out that although the Supreme Court had looked at the interrelationship between common law and indigenous customs it was also necessary to appreciate such interaction with the Constitution of South Africa. The Constitutional Court affirmed that 'like the common law, indigenous law is subject to any legislation, consistent with the Constitution, that specifically deals with it. In result, indigenous law feeds into, nourishes, fuses with and becomes part of the amalgam of South African law'. ${ }^{35}$ A crucial aspect of this decision from the South African courts is the reference to civil law. As the South African legal system is based on both Roman-Dutch law and English common law, it offers an interesting approach to the common law theory of aboriginal/native title by showing how such doctrine could be used outside a purely common law context, and, that potentially indigenous title doctrine is not limited to common law countries. ${ }^{36}$ Hence, even though the courts of South Africa have refused to specifically use the label 'aboriginal/native' title they have nonetheless integrated its main features within the South African legal order. ${ }^{37}$

Overall, there have been different approaches to a common law doctrine on indigenous peoples' land rights. Some national jurisdictions like in Malaysia have directly incorporated a common law doctrine whereas other jurisdictions such as in South Africa have indirectly integrated some elements of the common law doctrine. Despite these different approaches the decisions from Canada, Australia, New Zealand, Malaysia, Kenya, Belize, Botswana, and South Africa, are reflecting a common position regarding indigenous peoples' land rights. In their decisions, national courts have applied a high level of comparative analysis referring to a similar common law approach. At the heart

\footnotetext{
33 ibid para 8.

34 M Barry, 'Now another Thing must Happen: Richtersveld and the Dilemmas of Land Reform in Post-Apartheid South Africa' (2004) 20 SAJHR 355, 368.

35 Constitutional Court of South Africa, 2003 (12) BCLR 1301 (CC0) para 51.

36 This point is also supported by decision regarding indigenous peoples' land rights in Québec, see $R v$ Côté [1996] 3 SCR 139.

37 For a discussion on the implications/limits of such integration, see K Lehmann, 'Aboriginal Title, Indigenous Rights and the Right to Culture' (2004) 20 SAJHR 86.
} 
of such common denominator is the acknowledgment by national courts that indigenous peoples' land rights are grounded in their pre-existing customary laws which have survived colonization. These different decisions from national courts referring to a similar common law doctrine on indigenous peoples' land rights suggest the emergence of a unified jurisprudence on what could be labelled as a doctrine on 'indigenous title': a combination of aboriginal (the Canadian label) and native title (the Australian label).

\section{B. Common features of the common law doctrine}

Aboriginal or native title is a right to land. It is a collective title under which an indigenous community has the right to its use and occupation. ${ }^{38}$ The origins of such doctrine can be found in early decisions from the Privy Council, ${ }^{39}$ and $19^{\text {th }}$ century cases from the US Supreme Court. ${ }^{40}$ In terms of land law, within the common law the source of indigenous title could be found in the doctrine of 'acquired rights'. Under this doctrine, a change in sovereignty (by conquest or acquisition) does not affect the acquired property rights of the inhabitants. ${ }^{41}$ Under British colonial laws, when a conquest was made there were two approaches to the effect of the acquisition of territory on the customary land rights of the inhabitants. The first approach was based on the doctrine of continuity, which favoured the continuation of pre-existing customary land rights, the idea being that conquest did not adversely affect these rights unless there was an express legislative intent to do so. The second approach was based on the doctrine of recognition. This doctrine affirmed that rights to land had to be given formal recognition by the new power as annexation resulted in the abolition of all pre-existing rights. ${ }^{42}$ These rules on 'acquired rights' could be seen as one of the sources of the contemporary doctrine on indigenous title. The crucial point of the doctrine of aboriginal or native title is that the right to land of indigenous communities has its source in the occupation of land prior to the Crown's assertion of sovereignty. ${ }^{43}$

\footnotetext{
38 On the notion of exclusivity of such occupation, see High Court of Australia, Commonwealth v Yarmirr (2001) 208 CLR 1.

39 St Catherine's Milling and Lumber v The Queen (1889) 14 App Cas 46; Re Southern Rhodesia [1919] AC 211.

40 Johnson and Braham's Lessee v M'Intosh 21 US (8 Wheat) 1823; Cherokee Nation v Georgia 30 US 1 (1830); Worcester v Georgia, 31 US (1832).

41 eg the US Supreme Court in the 1833 case of United States $v$ Percheman affirmed that when there is a change of sovereignty: 'the people change their allegiance; their relation to their ancient sovereign is dissolved; but their relations to each other, and their right to property, remain undisturbed', United States v Percheman (1833) 7 Pet 6132 US, 87; see also: Certain Questions Relating to Settlers of German Origin in the Territory Ceded by Germany to Poland PCIJ Ser B No 6 (10 Sept 1923).

42 See, eg, Vajesingji Joravarsingji v Secretary of State for India (1924) LR 51 Ind App 357.

43 See High Court of Australia, Mabo v Queensland (No 2) (1992) 107 ALR 1, paras 89 and 182; Supreme Court of Canada, $R v$ Van der Peet 2 SCR (1996) 507, paras 18-19.
} 
The doctrine on indigenous title relies on the common law rule that interest in property which existed prior to the conquest of a territory by colonial powers survives such conquest, unless such interest has been formally extinguished by legislation. The roots of indigenous title are to be found in the indigenous customs and laws that preceded the acquisition of sovereignty by colonizers. Thus, these titles are based on the recognition of pre-existing indigenous laws, and on the common law principle that occupation is proof of possession. One of the main sources of indigenous title is indigenous customs. For example, in the 1992 groundbreaking Mabo case from the High Court of Australia, Justice Brennan pointed out that 'Native title has its origins in and is given its content by the traditional laws and customs acknowledged by and the traditional customs observed by the indigenous inhabitants of a territory'. ${ }^{44}$ Likewise, the Canadian approach remains based on the idea that aboriginal title relies on pre-existing indigenous customs. Canadian courts have affirmed that aboriginal title is sui generis as it based on both aboriginal laws and common law as 'Courts must not interpret Aboriginal rights using conventional common law doctrines alone because of the continued existence of prior Aboriginal legal regimes'. ${ }^{45}$ In South Africa, in the case of the Richtersveld Community, the Supreme Court held that disputes as to the right of an indigenous people to occupy traditional land are to be determined in the first instance by reference to indigenous law, without importing English concepts of property law. ${ }^{46}$ On the content and source of indigenous peoples' land rights, the Supreme Court of Appeal stated that: '[A]n interest in land held under a system of indigenous law is thus expressly recognised as a "right in land", whether or not it was recognised by civil law as a legal right' ${ }^{47}$ In Malaysia, the Sabah and Sarawak High Court in Nor Anak Nyawai observed that 'the common law respects the pre-existing rights under native law or custom' ${ }^{48}$ Hence, for the High Court the existence of a title to the land for the indigenous community does not depend on the existence of specific legislation but is based on their pre-existing customary rights. ${ }^{49}$ Such recognition of preexisting indigenous customary land rights was also at the heart of the cases from Kenya, Botswana, and Belize mentioned earlier. Overall, despite the particularity of each national system, the different national jurisdictions have affirmed that the existence of indigenous peoples' rights to their land is to be found in indigenous peoples' own customary laws.

\footnotetext{
${ }^{44}$ Mabo v Queensland (No 2) (1992) 107 ALR 1, 58.

45 J Borrows and L Rotman, 'The Sui Generis Nature of Aboriginal Rights: Does it make a Difference?' (1997) 36 Alta L Rev 9

${ }^{46}$ The Richtersveld Community $v$ Alexkor Limited and the Government of the Republic of South Africa, Case No 488/2001, Supreme Court of Appeal of South Africa (24 Mar 2003).

47 ibid para 9.

48 Nor Anak Nyawai v Borneo Pulp Plantation Sdn Bhd [2001] 2 Current Law Journal (Malaysia) 769.

49 See confirmation of such approach by the Court of Appeal in Kerajaan Negeri Selangor and 3 Ors v Sagong Bin Tasi and 6 Ors 2005 [CA].
} 
As such, the doctrine on indigenous title implies recognition of the possible cohabitation of two systems of laws, common law and indigenous law, within the same jurisdiction. As Pearson points out: 'Native title is neither a common law nor an Aboriginal law title but represents the recognition by the common law of title under Aboriginal law' ${ }^{50}$ For the first time in legal history, under this doctrine, courts have recognized the legal value of indigenous customary systems of land tenure. As highlighted by the Supreme Court of Canada, such recognition of indigenous customary laws is an attempt to achieve reconciliation by giving the same weight to aboriginal laws and the common law. ${ }^{51}$ In Van deer Pet, Chief Justice Lamer held that reconciliation of the prior occupation of North America by aboriginal peoples with the assertion of the Crown's sovereignty required that account be taken of the 'aboriginal perspective while at the same time taking into account the perspective of the common law'; as he concluded, 'true reconciliation will, equally, place weight on each' ${ }^{52}$ The doctrine could be seen as a bridge between indigenous and non-indigenous cultures as the same weight is given to both systems of law. From this perspective, the common law doctrine highlights the potential coexistence of a cross-cultural title to land for indigenous peoples. This is done from an historical perspective as indigenous title has its source in preexisting indigenous customs that predated the State legislation on property in lands. Accordingly, the common law doctrine does establish a clear link between dispossession that took place a long time ago and the present day situation. Thus, by putting the focus on pre-existing laws, the doctrine on indigenous title raises some issues regarding the timeframe of land occupation.

\section{THE WEIGHT OF HISTORY: CONTINUOUS VIOLATIONS AND TRADITIONS}

The common law doctrine on indigenous title reaches far back into history, as indigenous peoples would have their right to land recognized in light of events that took place centuries ago. Accordingly, the development of the doctrine raises difficult questions regarding the link between law and history. One of the first limitations on the relationship between law and history is the reference to the rule of intertemporal law. Under international law one of the fundamental legal difficulties when dealing with historical arguments is the reference to intertemporal law, as under this rule facts have to be judged by their contemporary standards. The following analysis wishes to examine how the common law doctrine proposes new readings on this relationship between law and history by inviting judges to decide on indigenous peoples' land rights based on their interpretation of historical events.

\footnotetext{
$50 \mathrm{~N}$ Pearson, 'The Concept of Native Title at Common Law' in Yunupingu (n 11).

51 For an illustration, see Supreme Court of Canada, Delgamuukw v British Columbia (1997) 3 SCR 1010.

${ }_{52}$ Lamer CJ in $R v$ Van der Peet [1996] 2 SCR 50, para 50.
} 


\section{A. Intertemporal law and 'continuing violation'}

When dealing with arguments of an historical nature one of the legal difficulties is the inherent limitation of intertemporal law. In the words of Judge Huber in the Island of Palmas arbitration 'a juridical fact must be appreciated in the light of the law contemporary with it, and not the law in force at the time when a dispute in regard to it arises or falls to be settled'. ${ }^{53}$ Under the doctrine of intertemporal law it is a well established legal rule that legal arguments should be assessed in the light of the rules of law that are contemporary with it. ${ }^{54}$ Hence, it is not possible for courts to look at past dispossession by using contemporary norms on indigenous peoples' land rights. However, if one looks carefully at the rule of intertemporal law and the often-quoted case of the Island of Palmas, there is another aspect to the doctrine. In the 1928 arbitration case, Judge Huber stated:

As regards the question which of different legal systems prevailing at successive periods is to be applied in a particular case (the so-called intertemporal law), a distinction must be made between the creation of rights and the existence of rights. The same principle which subjects the act creative of a right to the law in force at the time the right arises, demands that the existence of the right, in other words its continued manifestation, shall follow the conditions required by the evolution of law. ${ }^{55}$

As Elias pointed out, the first element of the rule, that acts should be judged in the light of the law contemporary with their creation, is widely accepted in international law. ${ }^{56}$ However, the second element, the reference to 'continued manifestation', remains controversial. ${ }^{57}$ The reference to continuous manifestation means that an act should be also judged having regard to the evolution of the law.

Applied in an indigenous peoples' land rights context the rule of intertemporal law seems to indicate two contradictory directions. In many ways the situation that indigenous peoples are facing today when it comes to land rights is the result of dispossession that took place in the past under theories of dispossession such as terra nullius, conquest or discovery. Thus, on the one hand, the rule suggests that such dispossession could be regarded as perfectly legal, as in most situations the reference to the rules of conquest, discovery or terra nullius were perfectly legal in this period of history. It is only under contemporary standards that they are illegal. This understanding of the rule would regard most of the dispossession that took place during the colonial era

53 Island of Palmas Arbitration 2 R Int'l Arb Awards 831 (1928).

54 See TO Elias, 'The Doctrine of Intertemporal Law' (1980) 74 AJIL 285.

55 Island of Palmas Arbitration 2 R Int'l Arb Awards 831 (1928).

56 Such reference would seem comparable to the principle of non retroactivity which is widely accepted at the national level.

57 Elias (n 54) 286. 
as legal. ${ }^{58}$ Yet, on the other hand, the rule of intertemporal law suggests that such acts of dispossession should also be appreciated in the light of the evolution of the law. And in many ways it could be argued that this is exactly what the common law doctrine on indigenous title is doing.

For example, the doctrine of terra nullius has been judged inadequate under contemporary legal standards on racial discrimination by the High Court of Australia. As the majority affirmed in the Mabo judgment, the international law notion that inhabited land may be classified as terra nullius no longer commands general support; hence: 'it is imperative in today's world that the common law should neither be nor be seen to be frozen in an age of racial discrimination' ${ }^{59}$ The references to 'continued manifestation' and 'evolution of the law' under the intertemporal law doctrine could have far-reaching consequences when applied to indigenous peoples' land rights, as in many cases the contemporary situation that indigenous peoples are facing is a direct consequence of the laws of colonization. Because the consequences of such a legacy are still at the centre of indigenous peoples' dispossession, it is possible to maintain that such rules of dispossession should be put in perspective with contemporary human rights law, in the sense that international law deals with past wrongs as long as they have current, ongoing effects, or as MacKay explains, with 'past and ongoing wrongs', as 'a past violation may have ongoing and continuing effects that are presently justiciable'. ${ }^{60}$

International institutions have acknowledged the ongoing and continuing effects of past wrongs on the contemporary situations faced by indigenous peoples. The reference to 'continuous manifestation' can be found in the jurisprudence of several international bodies dealing with indigenous peoples' rights. In the Lovelace case the Human Rights Council (HRC) was asked to adjudicate on a fact that took place in 1970, thus before the International Covenant on Civil and Political Rights (ICCPR) entered into force. Even though the HRC pointed out that it could not examine allegations relating to events that had taken place before the entry into force of the Covenant, it determined its competence in the case based on the notion of 'continuing effect'. The HRC stated: '[T]his fact persists after the entry into force of the Covenant, and its effects have to be examined without regard to their original cause'. ${ }^{61}$ More specifically, regarding indigenous peoples' land rights, in the case of Ominayak $v$ Canada, the Committee concluded that the historical inequity of the failure to assure the Lubicon Lake Band land ownership through reservation threatened their way of life and constituted a violation of

\footnotetext{
58 With some limitations on conquest, see Gilbert (n 6) ch 2.

59 Mabo v Queensland (No 2) [1992] HCA 23; (1992) 175 CLR 1 FC 92/014 (3 June 1992), para 41.

${ }^{60}$ F MacKay, Addressing Past Wrongs, Indigenous Peoples and Protected Areas: The Right to Restitution of Land and Resources (Oct 2002), at <http://www.forestpeoples.org/documents/law hr/ips_restitution_protected_areas_oct02a_eng.pdf>.

${ }^{61}$ Sandra Lovelace v Canada, Communication No 24/1977 (14 Aug 1979), UN Doc $\mathrm{CCPR} / \mathrm{C} / \mathrm{OP} / 1$ (1984) 10, paras 10,11, 12, and 13.
} 
Article 27. The Committee stated: ' $[\mathrm{H}]$ istorical inequities to which the State party refers, and certain more recent developments, threaten the way of life and culture of the Lubicon Lake Band, and constitute a violation of Article 27 so long as they continue'. ${ }^{62}$ What was decisive in Ominayak was that a series of incremental adverse events could together constitute a 'historical inequity' which amounted to a violation of Article 27. While the mandate of the HRC does provide for inquiries into past events that took place before ratification by the State Party, the HRC has shown that past wrongs could constitute a continuous violation of the contemporary rights enjoyed by indigenous peoples under the ICCPR. ${ }^{63}$

This reference to historical inequities is not limited to the $\mathrm{HRC}$; the International Labour Organization (ILO) Committee which receives representation regarding the implementation of ILO Convention 169 at national level has also dealt with arguments of an historical nature. ${ }^{64}$ In a case filed by the Radical Trade Union of Metal and Associated Workers on behalf of the Chinantec indigenous community in Mexico, one of the legal issues was that the displacement of the concerned indigenous community from their land took place before Mexico's ratification of ILO 169. The Government of Mexico challenged the Committee's competence in examining events that took place before Mexico's ratification. The ILO Committee stated:

... the effects of the decisions that were taken at that time continue to affect the current situation of the indigenous peoples in question, both in relation to their land claims and to the lack of consultations to resolve those claims. The Committee therefore considers that the Convention does currently apply with respect to the consequences of the decisions taken prior to its entry into force. ${ }^{65}$

The Committee adopted a similar position in a decision against Denmark when it stated: 'the effects of the 1953 relocation continue today, in that the relocated persons cannot return to the Uummannaq settlement and that legal claims to those lands remain outstanding' ${ }^{66}$ Accordingly, the Committee decided:

... that the consequences of the relocation that persist following the entry into force of Convention No. 169 still need to be considered with regard to Articles

${ }^{62}$ Lubicon Lake Band v Canada, Communication No 167/1984 (26 Mar 1990), UN Doc Supp No 40 (A/45/40) (1990) 1, para 33.

63 See Simunek, Hastings, Tuzilova and Prochazka v The Czech Republic, Communication No 516/1992, UN Doc CCPR/C/54/D/516/1992 (1995).

${ }^{64}$ Representations under Art 24 of the ILO Constitution may be made by employers' and workers' organizations who claim that a State has failed to observe a ratified Convention. For details, see <http://www.ilo.org>.

${ }^{65}$ Report of the Committee set up to examine the representation alleging non-observance by Mexico of the Indigenous and Tribal Convention, 1989 (No 169), made under Art 24 of the ILO Constitution by the Radical Trade Union of Metal and Associated Workers, Doc GB.273/15/6; GB. $276 / 16 / 3$

${ }^{66}$ Report of the Committee set up to examine the representation alleging non-observance by Denmark of the Indigenous and Tribal Convention, 1989 (No 169), made under Art 24 of the ILO Constitution by the Sulinermik Inuussutissarsiuteqartut Kattuffiat (SIK), Doc GB.277/18/3; GB.280/18/5, submitted 1999 . 
14(2) and (3), 16(3) and (4) and 17 of the Convention, examined below, despite the fact that the relocation was carried out prior to the entry into force of the Convention. 67

This position has been affirmed in other cases brought to the ILO Committee. ${ }^{68} \mathrm{~A}$ similar approach has been followed by the Inter-American Commission on Human Rights, which in the case of Mary and Carrie Dann affirmed that to the extent that the concerned indigenous peoples remain the victims of 'an on-going violation of their rights', then the State is obliged to resolve the situation in light of its contemporary obligations under international human rights law. ${ }^{69}$ Likewise, the Inter-American Court of Human Rights has established a doctrine of 'continuing violation', allowing the judge to examine historical events that have consequences for indigenous peoples' contemporary rights under the Inter-American Convention. ${ }^{70}$ Thus, even though international human rights bodies such as the HRC or the InterAmerican Commission as well as the ILO Committee would not directly address past dispossession, they would take into consideration the historical inequities that led to the situation facing indigenous peoples. The rationale is based on a link between historical dispossession and the present situation; therefore, it could be deduced that human rights bodies and courts would not address past dispossession unless it is linked with a present violation. In the case of indigenous peoples' land rights it means that the indigenous community must still have a link with its territory. The community claiming a right to the land should still exercise some form of occupation of the land. The doctrine of continuous violation or past ongoing violations would only allow courts or monitoring bodies the examination of past dispossession in the light of present-day occupation by indigenous peoples, but would not allow a total revision of past dispossession.

This focus on present-day occupation of the lands is also reflected in the common law doctrine. Under the doctrine on indigenous title, indigenous peoples' right to their land would be recognized by national jurisdictions to the extent that indigenous communities have survived dispossession and still live on parts of their lands. In other words courts look at present-day occupation only. In Mabo the High Court set down the requirement that there must be 'substantial maintenance of the connection' between the people and the land. Exploring the criteria of present-day occupancy in Australia, Reilly pointed out that 'the main practical significance of Mabo was that it left open the

\footnotetext{
67 ibid.

68 Report of the Committee set up to examine the representation alleging non-observance by Ecuador of the Indigenous and Tribal Convention, 1989 (No 169), made under Art 24 of the ILO Constitution by the Confederación Ecuatoriana de Organizaciones Sindicales Libres (CEOSL), Doc GB.277/18/4, GB.282/14/2, submitted 2000.

69 Mary and Carrie Dann v United States, Case 11.140, Report No 75/02, Doc 5 rev 1 (2002) 860 , see para $167-$ IACHR.

70 See P Ormanecha, 'Moiwana Village: The Inter-American Court and the "Continuing Violation” Doctrine' (2006) 19 Harvard Human Rights Journal, 283.
} 
possibility that to the extent indigenous communities have survived dispossession from their land, they possess a title to the land based on their traditional laws and customs'. ${ }^{71}$ As the author concluded, indigenous title 'protects what remains of the unique relationship to land of the indigenous peoples' ${ }^{72}$ Likewise, as Lehmann points out, even though the requirement of present-day occupation is not explicitly affirmed in Canadian jurisprudence, it seems clear that the doctrine of aboriginal title would offer protection to present relationships with the land. ${ }^{73}$ For example, in the Delgamuukw case the Supreme Court of Canada insisted that one of the crucial criteria to establish aboriginal title is that the community has maintained a substantial connection between the people and the land. ${ }^{74}$ Thus, even though the courts would receive evidence of past occupation through indigenous customs, physical occupation of the land by the indigenous community is a fundamental criterion to recognize their title. Lehmann sees this point as the principal limit to the application of the doctrine in South Africa. She wrote:

The most serious limitation on the doctrine as a form of redress, is the fact that the doctrine protects only existing relationships with land, relationships that exist by virtue of the fact that at the time the colonising power asserted sovereignty, the claimant group was in occupation of the particular territory claimed, and by virtue of the fact that the claimant group has remained in occupation of that territory to the present day. ${ }^{75}$

This statement highlights how the doctrine does not address the situation of indigenous communities that have been forcibly removed from their lands as they would not fulfil the criteria of occupancy. In other words, the doctrine does not address the issue of restitution for past dispossession. Nonetheless, as stated above, the doctrine tries to establish a bridge between the past and the present through its recognition of indigenous peoples' own customary laws and its reference to indigenous traditions over their lands and territories. Hence, while the common law doctrine also relies on the limitation of presentday occupation, it goes further than international law by proposing a much more comprehensive legal theory on the relationship between indigenous traditional customary systems of laws and contemporary land claims.

\section{B. From 'frozen rights' to 'cultural continuity'}

Indigenous title is based on the existence of pre-existing customary indigenous laws. The recognition of indigenous peoples' land rights relies on proof that the indigenous community has maintained a 'traditional' use of its lands throughout the centuries. National courts have put the burden of proof on

71 A Reilly, 'The Australian Experience of Aboriginal Title: Lessons for South Africa' (2000) 16 SAJHR 512, 515.

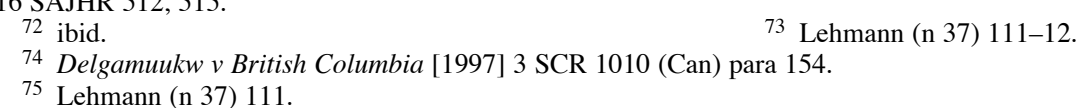


indigenous peoples to prove the contemporary existence of their traditional law. Hence, one of the difficulties in applying the doctrine of indigenous title is its reference to tradition. This reference to 'traditional ways of using the land' could be seen as extremely static, as a strict interpretation means that indigenous peoples have to use their land in the way they did centuries ago. This position is often referred to as the 'frozen rights' approach, as under this theory indigenous peoples' right to land would be evaluated on whether or not the concerned indigenous community has maintained a way of life which was the same prior to colonization. This means that indigenous peoples would be granted the right to use and occupy their lands only if they conform to traditional laws and customs; if such practices have evolved, their rights over lands would not be recognized. The legal challenge is to appreciate whether a traditional use of the land has been observed continually since colonization.

While this issue has been touched upon at the international level, the legal theory on the relationship between traditional use of land and contemporary land claims remains limited. The most developed analysis on this issue comes from the Human Rights Committee (HRC). The HRC has developed a cultural approach to indigenous peoples' land rights through Article 27 of the ICCPR. In its General Comment on Article 27 the Committee stated:

With regard to the exercise of the cultural rights protected under article 27, the Committee observes that culture manifests itself in many forms, including a particular way of life associated with the use of land resources, especially in the case of indigenous peoples. That right may include such traditional activities as fishing or hunting and the right to live in reserves protected by law. ${ }^{76}$

This reference to traditional activities was delineated in a case concerning the Saami community in Finland, where the Committee stated that

article 27 does not only protect traditional means of livelihood of national minorities, as indicated in the State party's submission. Therefore, that the authors may have adapted their methods of reindeer herding over the years and practice it with the help of modern technology does not prevent them from invoking article 27 of the Covenant. ${ }^{77}$

Likewise, in a case concerning fishing rights in New Zealand, the HRC confirmed this approach. It stated: 'The right to enjoy one's culture cannot be determined in abstracto but has to be placed in context. In particular, article 27 does not only protect traditional means of livelihood of minorities, but allows also for adaptation of those means to the modern way of life and ensuing technology'. ${ }^{78}$ The Committee clearly recognized that the cultural protection

\footnotetext{
76 General Comment No 23: The rights of minorities (Art 27): UN Doc CCPR/C/21/Rev.1/Add.5, General Comment No 23. (General Comments) para 7.

77 I Länsman v Finland (Communication No 511/1992), UN Doc CCPR/C/52/D/511/1992, para 9.3.

78 Apirana Mahuika $v$ New Zealand, Communication No 547/1993, UN Doc CCPR/C/70/D/547/1993 (2000) para 9.4.
} 
offered under Article 27 was not to be seen as 'frozen' as it also protects indigenous peoples' contemporary use of their lands. For example, the use of helicopters for reindeer herding or the use of modern-day fishing technology by indigenous peoples would not preclude them from their cultural rights protected under Article 27 of the ICCPR. The indigenous community would still have to prove that the activity is part of their traditional way of life, but not in a frozen rights manner, as such activity could have evolved over the centuries.

This connection between traditional use of a territory and land rights is central to the common law doctrine on indigenous title, for indigenous title is based on the recognition of indigenous peoples' pre-existing use of their lands. In Canada, to be recognized as an aboriginal right, an indigenous practice must be integral to the distinctive culture asserting the right, and such practice must be persisting today. This test of 'continuity' demands that indigenous peoples prove the 'traditional' aspect of their practice. ${ }^{79}$ Yet the Supreme Court has rejected a frozen approach. For example, an aboriginal right to fish and hunt has been recognized as belonging to a community using nylon nets and highpowered rifles. ${ }^{80}$ Regarding aboriginal title, the Supreme Court ruled that aboriginal title to land should allow aboriginal peoples to exercise their way of life in a contemporary manner. In the Delgaтииkw case the Supreme Court adopted the view that aboriginal title should not be seen as frozen in time, since it encompasses the use and occupancy of the land for a variety of purposes ${ }^{81}$ However, Chief Justice Lamer added that:

... lands subject to aboriginal title cannot be put to such uses as may be irreconcilable with the nature of the occupation of that land and the relationship that the particular group has had with the land which together have given rise to aboriginal title in the first place. ${ }^{82}$

As pointed out by McNeil, the Supreme Court imposed an 'inherent limit' on aboriginal title..$^{83}$ Chief Justice Lamer stated that if the aboriginal peoples 'wish to use their lands in a way that aboriginal title does not permit, then they must surrender those lands and convert them into non-title lands to do so' ${ }^{84}$ Nonetheless, despite such limitations, the Canadian legal system has usually adopted what Connolly calls a 'legal doctrine of change'. ${ }^{85}$ As the author highlights: 'according to this doctrine, some degree of change in the content of an indigenous practice over the period of time since colonisation does not render that practice ineligible for legal recognition and protection', ${ }^{86}$ Under

79 See notably $R v$ Van der Peet [1996] 2 SCR 50, para 40.

80 See $R v$ Sparrow [1990] 1 SCR 1075; and $R v$ Badger [1996] 1 SCR 771.

81 Delgamuukw v British Columbia [1997] 3 SCR 1010 (Can) 1095, para 138

82 ibid 1089 , para 128.

83 K McNeil, 'The Post-Delgamuukw Nature and Content of Aboriginal Title' (Osgoode Hall Law School, Toronto, 2000).

84 Delgamuukw v British Columbia [1997] 3 SCR 1010 (Can) 1091, para 131.

85 A Connolly, 'Judicial Conceptions of tradition in Canadian Aboriginal Rights Law' (2006)

7 Asia Pacific Journal of Anthropology 27.

86 ibid 33. 
the legal doctrine of change, the legal institutions have opted for a 'dynamic right' approach towards indigenous customs. As Justice L'Heureux-Dube stated in Van der Peet:

The most appreciable advantage of the 'dynamic right' approach to defining the nature and extent of aboriginal rights is the proper consideration given to the perspective of aboriginal people on the meaning of their existing rights. It recognizes that distinctive aboriginal culture is not a reality of the past, preserved and exhibited in a museum, but a characteristic that has evolved with the natives as they have changed, modernized and flourished over time, along with the rest of Canadian society. 87

As the Chief Justice of the Supreme Court in Delgamuukw also stressed, imposing the requirement of continuity too strictly would risk 'perpetuating the historical injustices suffered by aboriginal peoples at the hands of colonisers who failed to respect aboriginal rights to land'. ${ }^{88}$ As Chief Justice Lamer stated 'the evolution of practices, customs and traditions into modern forms will not ... prevent their protection as aboriginal rights ... provided that continuity with pre-contact practices, customs and traditions is demonstrated' ${ }^{89}$ This reference to continuity has to be seen as one of the core issues in determining aboriginal title.

Likewise, this reference to continuity is one of the key elements in determining native title in Australia. On the issue of continuity, the case of the Yorta Yorta community is often seen as a turning point for its reference to the 'tide of history'. In his decision at first instance, Olney $\mathbf{J}$ rejected the claim from the members of the Yorta Yorta community on the main ground that there was not enough evidence proving that the concerned indigenous community had continued to observe and acknowledge 'the traditional laws and customs in relation to land of their forbears' ${ }^{90}$ As the judge concluded: 'The tide of history has indeed washed away any real acknowledgement of their traditional laws and any real observance of their traditional customs' ${ }^{91}$ In this case before the High Court of Australia, the judges rejected the claim of the indigenous community as the observance of traditional law and custom have not been continuous since the establishment of sovereignty by the British over Australia in 1788. As Gleeson CJ, Gummow and Hayne JJ pointed out, only the laws and customs which existed 'before the assertion of sovereignty by the British Crown' are to be regarded as authentically traditional for the purposes of native title law. ${ }^{92}$ Explaining the meaning of 'traditional' the judgment states:

'Traditional' in this context must be understood to refer to the body of law and customs acknowledged and observed by the ancestors of the claimants at the time

$87 R v$ Van der Peet [1996] 2 SCR 507, para 179.

88 Delgamuukw v British Columbia [1997] 3 SCR 1010 (Can) para 153 (Lamer CJ).

$89 R v$ Van der Peet [1996] 2 SCR 50, para 64.

90 Yorta Yorta Aboriginal Community v Victoria [1998] FCA 1606, para 129.

91 ibid. 
of sovereignty [which must have] continued substantially uninterrupted. . . . Were that not so, the laws and customs acknowledged and observed now could not properly be described as traditional laws and customs of the people concerned. ${ }^{93}$

As Reilly and Genovese point out, when an indigenous community claims its rights to native title it has to prove first the existence of traditional laws and customs in the past, secondly the observance of traditional laws and customs in the present, and thirdly establish a connection between the two such that laws and customs can be said to have been substantially maintained across time. ${ }^{94}$ As the authors observe, the case of the Yorta Yorta community 'permanently disrupted the assumption that law and history are able to speak to each other'. ${ }^{95}$ Brennan comments on this decision:

On the one hand, the system of Aboriginal law and custom must demonstrate a 'continuous existence and vitality since sovereignty' (at [47] Gleeson CJ, Gummow and Hayne JJ). Yet on the other hand, if that vitality has extended to the generation of new social structures and new law and custom since 1788 to take account of European colonisation, it seems it will surrender its 'traditional' character and forfeit the possibility of recognition by the judges of the colonising people (at [54] Gleeson CJ, Gummow and Hayne JJ).

In its 2005 concluding observations to Australia's report under the International Convention on the Elimination of all forms of Racial Discrimination (ICERD), the Committee on the Elimination of Racial Discrimination (CERD) examined the consequences of the standard of proof established in the Yorta Yorta community case. CERD expressed its concerns 'about information according to which proof of continuous observance and acknowledgement of the laws and customs of indigenous peoples since the British acquisition of sovereignty over Australia is required to establish elements in the statutory definition of native title under the Native Title Act'. CERD pointed out that such a 'high standard of proof required is reported to have the consequence that many indigenous peoples are unable to obtain recognition of their relationship with their traditional lands (Art 5)'. The Committee recommended that the State Party review the requirement of such a high standard of proof, bearing in mind the nature of the relationship of indigenous peoples to their land. 96

Overall, there is a danger that by relying on the past, the indigenous title doctrine relies too much on a specific legal translation of history. As Reilly and Genovese note in the Australian context, "constructing native title in such a way that they are required to exist in the same form outside of the time and context of their creation is ahistorical ... to interpose rights from the past into

93 ibid, majority judgment, Gleeson CJ, Gummow and Hayne JJ, paras 86-7.

94 Reilly and Genovese (n 13).

95 ibid 21.

96 Concluding observations of the Committee on the Elimination of Racial Discrimination: Australia, UN Doc CERD/C/AUS/CO/14 (14 Apr 2005) para 17. 
the present and expect their nature and extent to be unchanged requires a similitude between conditions in the past and the present that gives a false notion of history'. ${ }^{97}$ The authors raise doubt about the actual capacity of the doctrine as a good vector between the past and the present by nature of its being too metahistoric in its approach towards indigenous peoples' own account of history. ${ }^{98}$ By hinging too much on the past the doctrine seems to lose its credibility as a potential bridge between past dispossession and present-day occupation. Moreover, the indigenous title doctrine shows dangerous signs of adopting a one-sided approach to history, as the doctrine appears biased against indigenous peoples' forms of traditions and oral history. In determining indigenous title to land, judges rely on historical accounts (usually in their written forms), and assume that such historical accounts tell the whole story on how indigenous customary systems were in the past.

\section{ERASING THE PAST: EXTINGUISHMENT VERSUS HUMAN RIGHTS}

Under the doctrine of indigenous title, an indigenous community would have its collective title to the land recognized only if such historical title had not been extinguished. Indigenous title could be explicitly extinguished by an act whose purpose is the extinguishment of the title, or implicitly by an act that creates a situation that would ultimately extinguish the title. The general rule regarding extinguishment is that the legislative power should pass a valid act that exhibits a clear and plain intention to extinguish indigenous title. ${ }^{99}$ The requirement of a plain and clear legislative intention is a common feature of most of the jurisdictions recognizing indigenous title. ${ }^{100}$ The legislature's intention would be determined by an objective test as the intention has to be found in the words of the act itself and not in the state of mind of the legislators. ${ }^{101}$ However, the practice of extinguishment raises several questions regarding fundamental international legal human rights standards on equality and non-discrimination, as extinguishment only affects indigenous peoples. Extinguishment also raises some issues regarding indigenous peoples' right to participation in decisions affecting them, as the legislature can potentially extinguish indigenous peoples' right over their lands without consultation with the concerned communities.

\footnotetext{
97 Reilly and Genovese (n 13) 38.

98 As the authors highlights in this context metahistory 'means the propounding of universal explanations of historical processes', ibid 36.

99 Supreme Court of Canada: $R$ v Sparrow [1990] 1 SCR 1075.

100 See S Dorsett, 'Clear and Plain Intention Extinguishment of Native Title in Australia and Canada post-Wik’ (1997) 6 Griffith Law Review 96.

101 See, eg, High Court of Australia, Western Australia v Ward; Attorney General (NT) v Ward; Ningamara $v$ Northern Territory; Ward v Crosswalk Pty Ltd [2002] HCA 28.
} 


\section{A. Equality and non-discrimination}

The procedures concerning extinguishment of indigenous title raise questions regarding the norms of equality and non-discrimination. Because indigenous title is a title only recognizable to indigenous peoples, in return the procedures surrounding its extinguishment are also specific to indigenous peoples. No other title to land is susceptible to being extinguished. Indigenous title is extremely vulnerable as it could extinguish by the legislative or executive power 'in circumstances where other titles to land are not' ${ }^{102}$ Only indigenous title is at risk of being extinguished, hence such procedures do create specific norms that could be seen to be in violation of the principles of equality and non-discrimination. Moreover, the notion of extinguishment raises some issues regarding equality and non-discrimination as indigenous title is subordinated to the rights of third parties. Extinguishment makes indigenous title a very vulnerable right for indigenous peoples as their land rights could be extinguished under pressure from third-party interest in their lands. As McNeil points out, in Canada and Australia aboriginal or native title is extremely vulnerable to the creation of third-party interests by the Crown. ${ }^{103}$ For example, in the 1992 Mabo decision the High Court of Australia held that pre-existing indigenous land rights would have been extinguished to the extent that they were inconsistent with either a real property interest granted by the Crown or any other form of appropriation and use of their lands by the Crown prior to the enactment of the 1975 Racial Discrimination Act (Cth) ${ }^{104}$ Thus, regarding rights in land, the court recognized that titles granted by the Crown could potentially extinguish indigenous titles if they were inconsistent with other titles granted by the Crown. Likewise, McNeil demonstrates how in the Delgamuukw decision the Supreme Court of Canada 'has prepared the way for giving precedence to private interests by providing the Crown with broad powers to infringe Aboriginal title, even for such purposes as agriculture, forestry, and mining'. ${ }^{105}$ As this author observes, the application of different standards between indigenous title and non-indigenous titles, with the former having superiority over the latter, is certainly hindering the establishment of a truthful reconciliation process. ${ }^{106}$ From this perspective, the common law doctrine on indigenous title clearly creates a hierarchy regarding land rights with indigenous peoples' rights being subject to extinguishment by other nonindigenous titles.

In her report on indigenous peoples and their relationship to land, UN Special Rapporteur Erica Daes emphasized that extinguishment is a procedure

102 N Pearson, 'Principles of Communal Native Title' (2000) 5 ILB 19.

$103 \mathrm{~K} \mathrm{McNeil,} \mathrm{'The} \mathrm{Vulnerability} \mathrm{of} \mathrm{Indigenous} \mathrm{Land} \mathrm{Rights} \mathrm{in} \mathrm{Australia} \mathrm{and} \mathrm{Canada'} \mathrm{(2004)}$ 42 Osgoode Hall L J 271-302.

104 Mabo v Queensland (No 2) (1992) 175 CLR 1.

105 McNeil (n 103) 271.

106 ibid. 
applied only against indigenous peoples. She wrote: 'Aboriginal title is normally subject to complete extinguishment by the Government of the State, without the legal protection and rights that in most countries protect the land and property of citizens'. ${ }^{107}$ Thus, she noted that the concept of aboriginal title is by itself discriminatory as 'it provides only defective, vulnerable and inferior legal status for indigenous land and resource ownership'. ${ }^{108}$ Extinguishment suppresses all the rights of indigenous peoples, even those of occupation and the right to use their lands. Extinguishment is an act of total and absolute confiscation with no recourse, which goes against the increasing recognition in international law of the special and fundamental relationship that indigenous peoples have with their lands. Matthew Coone, a Cree Grand Chief, when addressing the Canadian Royal Commission on Aboriginal Peoples stated: '. . . the doctrine of terra nullius is being rejected as a racist construct and a breach of human rights. Extinguishment is simply terra nullius applied after the fact'. 109

However, even though extinguishment appears to be in contradiction with the notion of equality and non-discrimination, this avenue has rarely been examined by the UN treaty-monitoring bodies. Despite the fact that the fight against discrimination and for equality is the 'golden thread' of international legal human rights discourse, apart from a few exceptions, neither the HRC nor the CERD have explicitly addressed the issue of extinguishment as regards its compatibility with non-discrimination or equality. To date the UN committees have looked at extinguishment in precise context only. For example, in the case of New Zealand, using its early-warning mechanism, CERD specifically expressed its concern regarding the impact on the 2004 legislation on the Foreshore and Seabed, ${ }^{110}$ highlighting that 'the legislation appears to the Committee, on balance, to contain discriminatory aspects against the Mâori, in particular in its extinguishment of the possibility of establishing Mâori customary title over the foreshore and seabed...' ${ }^{111}$ Likewise, the HRC has commented on the practice of extinguishment in the context of treaty rights in Canada. ${ }^{12}$ But overall, there is no clear analysis on the compatibility of the practice of extinguishment with international norms on equality and nondiscrimination.

The most elaborate decision on this link between non-discrimination and extinguishment comes from the Inter-American Commission of Human Rights (IACHR), which has explored the relationship between the theory of extin-

107 EI Daes, Special Rapporteur, 'Human Rights of Indigenous Peoples: Indigenous People and their relationship to land' Working Paper, UN Doc E/CN.4/Sub.2/1997/17, para 29.

108 ibid para 31.

109 Presentation to the Royal Commission on Aboriginal Peoples by the Grand Council of the Cree (Eeyou Astchee) Montreal, Québec, 18 Nov 1993, 7.

110 Foreshore and Seabed Act 2004 (FSA).

111 CERD, Decision 1 (66), para 6 UN Doc CERD/C/66/NZL/Dec 1.

112 Concluding observations of the Human Rights Committee, UN Doc CCPR/C/CAN/CO/5 (2005), para 8. 
guishable indigenous title to territory and human rights in the case of Mary and Carrie Dann $v$ United States. ${ }^{113}$ In this case the petitioners, both members of the Western Shoshone indigenous community, alleged that the US Government had interfered with the use and occupation of their ancestral lands, thus violating some of their rights guaranteed by the American Declaration of the Rights and Duties of Man. The Government argued that 'the Danns and other Western Shoshone lost any interest in the lands in question in 1872 as a result of encroachment by non-Native Americans . . . ${ }^{114}$ The Government contended that such extinguishment was confirmed by a decision of the Indian Claims Commission that had concluded that Western Shoshone title to land had been extinguished. ${ }^{115}$ However, the Danns contested the extinguishment of their rights as discriminatory contrary to Article II of the Declaration, which protects the right to equality before the law. The petitioners challenged the State assumption on extinguishment by asserting that the Government had failed to protect their land rights by not according those rights the same degree of protection that it provides for the protection of the property rights of non-Indians. ${ }^{116}$ More specifically regarding the issue of extinguishment by third party rights, the petitioners argued that the 'gradual encroachment by non-indigenous settlers, miners and others, constitutes a non-consensual and discriminatory transfer of property rights in land away from indigenous people who continue in possession of their land and in favour of non-indigenous interests'. ${ }^{117}$ The Government maintained that the concerned communities had lost any interest in the lands in question as a result of this encroachment by non-native Americans, and that this determination was properly made through proceedings before the Indian Claims Commission (a quasi-judicial body established for the very purpose of determining Indian land claims issues). ${ }^{118}$ For the IACHR, one of the crucial issues was to assess whether any part of such property rights remained un-extinguished, notably looking at the issue of equality. ${ }^{119}$ The Commission stated:

While the State has suggested that the extinguishment of Western Shoshone title was justified by the need to encourage settlement and agricultural developments in the western United States, the Commission does not consider that this can justify the broad manner in which the State has purported to extinguish indigenous claims, including those of the Danns, in the entirety of the Western Shoshone territory. ${ }^{120}$

\footnotetext{
113 Inter-American Commission on Human Rights, Mary and Carrie Dann v United States Report No 113/01, Case No 11.140 (15 Oct 2001).

114 ibid para 3.

115 See Shoshone Tribe v US 11 ICC 387 (1962).

116 Mary and Carrie Dann $v$ United States (n 62) para 53.

117 ibid.

118 ibid para 82.

119 Mary and Carrie Dann v United States, Case 11.140, Report No 75/02, Inter-Am CHR, Doc 5 rev 1 at 860 (2002) 27, para 100.

120 ibid 41, para 145.
} 
On this issue, the IACHR concluded 'that the Danns have not been afforded equal treatment under the law respecting the determination of their property interests in the Western Shoshone ancestral lands, contrary to Article II of the Declaration'. ${ }^{121}$ Even though the IACHR did not address the issue of whether or not the indigenous peoples' right of ownership had been completely extinguished, it set out the guideline that any process of extinguishment should be in conformity with fundamental guarantees of equality before the law. In reaching this conclusion, the IACHR also highlighted that the practice of extinguishment raises some issues regarding the right of indigenous peoples to participate in the determination of their claims to property rights.

\section{B. Effective participation and free and informed consent}

The practice of extinguishment usually relies on unilateral decisions from the State's authorities in which indigenous peoples have no say. As highlighted above in the case of Mary and Carrie Dann, the IACHR has criticized US policy on extinguishment violating the rights of indigenous peoples to be fully informed and consulted in decisions affecting them. Based on Articles XVIII (right to fair trial) and XXIII (right to property) of the American Declaration, the Commission pointed out that States have an obligation

to ensure that any determination of the extent to which indigenous claimants maintain interests in the lands to which they have traditionally held title and have occupied and used is based upon a process of fully informed and mutual consent on the part of the indigenous community as a whole. ${ }^{122}$

The onus is on the State to ensure that the whole concerned indigenous community is informed and consulted before any decision regarding their lands is made. While in this case the IACHR relied on the right to fair trial and the right to property enshrined in the American Declaration (to which the US is a party), this association between the practice of extinguishment and the right for indigenous peoples to be fully informed and consulted opens the door to a whole body of international law on indigenous peoples' right to political participation. Extinguishment may clearly be found to contravene the right to participation of indigenous peoples in decisions affecting them in relation to their lands and territories.

In its General Comment 23, the HRC affirmed that indigenous communities must have effective participation in decisions that affect the community, especially where culture manifests itself in a particular way of life associated with the use of land resources. ${ }^{123}$ In the Länsmann case, the HRC affirmed

121 ibid para 145 .

122 Mary and Carrie Dann v United States (n 62) para 140.

123 Human Rights Committee, General Comment 23, Art 27 (55th session, 1994), Compilation of General Comments and General Recommendations Adopted by Human Rights Treaty Bodies, UN Doc HRI\GEN\1\Rev.1 (1994) 38, para 7. 
that when undertaking acts that might infringe indigenous peoples' rights, States have a duty to consult indigenous peoples. ${ }^{124}$ This indicates that potentially the theory of unilateral, extinguishable native title could be seen as contrary to the rights of indigenous peoples to participate in decisions affecting their territories as enshrined in Article 27 of the ICCPR. Thus, even though the HRC has not directly dealt with the issue of the legality of the doctrine of the extinguishment of indigenous title to territory through its individual complaints mechanisms, there are many ways by which indigenous peoples could argue against such discriminatory acts. The dialogue between Canada and the HRC through the monitoring procedures of the Committee shows further interrelationship between rights enshrined in the ICCPR and the practice of extinguishment. In its 1999 concluding observations concerning the report from Canada, the HRC recommended 'that the practice of extinguishing inherent Aboriginal rights be abandoned as incompatible with article 1 of the Covenant'. ${ }^{125}$ Thus, the HRC established a clear link between self-determination and the practice of extinguishment, as self-determination implies a right of the concerned people to participate in decisions affecting them. More recently, in its 2006 concluding observations on Canada's report, the HRC pointed out that the practice of extinguishment in modern treaties between aboriginal peoples and the Government raised some issues regarding Articles 1 and 27 of the ICCPR. ${ }^{126}$ Hence, overall the practice of extinguishment engages indigenous peoples' rights under the ICCPR which gives indigenous peoples a right to participate in decisions affecting them.

This contradiction between the practice of extinguishment and international standards on political participation is not limited to the ICCPR as several other international instruments insist on indigenous peoples' right to participation and consultation in decisions affecting them. Under international law there has been some debate on whether indigenous peoples do have a specific right to effective participation which could be translated into a right to free and informed consent to decisions affecting their lands. ${ }^{127}$ Article 16 of the ILO Convention 169 clearly affirms that relocation of indigenous peoples from their lands should take place only with their free and informed consent. The whole spirit of the UN Declaration on the Rights of Indigenous Peoples adopted by the Human Rights Council is based on the notion of partnership between indigenous peoples and States. The practice of extinguishment seems particularly contrary to the idea of free and informed consent enshrined in Article 32 of the declaration. CERD, in its General Recommendation XXIII,

\footnotetext{
124 Länsman v Finland, Communication No 511/1992, UN Doc CCPR/C/52/D/511/1992, para 9.5.

125 Concluding observations of the Human Rights Committee, Canada, UN Doc CCPR/C/79/Add.105, para 8 (1999).

126 Concluding observations of the Human Rights Committee, Canada, UN Doc $\mathrm{CCPR} / \mathrm{C} / \mathrm{CAN} / \mathrm{CO} / 5$, para 8 (2006).

127 eg see comments by the Government of Australia on the concluding observations of the Committee on the Elimination of Racial Discrimination, UN Doc CERD/C/AUS/CO/14/Add.1 (2006).
} 
pointed out that States Parties to ICERD have to 'ensure that members of indigenous peoples have equal rights in respect of effective participation in public life and that no decisions directly relating to their rights and interests are taken without their informed consent'. ${ }^{128}$ Decisions affecting indigenous peoples' land rights would certainly fall into this category of 'decisions directly affecting them'; hence States would have to make sure that any decisions affecting indigenous peoples' land rights would be taken with their free and informed consent. In the same General Comment, CERD stated:

The Committee especially calls upon States parties to recognize and protect the rights of indigenous peoples to own, develop, control and use their communal lands, territories and resources and, where they have been deprived of their lands and territories traditionally owned or otherwise inhabited or used without their free and informed consent, to take steps to return those lands and territories. ${ }^{129}$

In its concluding observations to Australia's report, CERD recommended that Australia 'make every effort to seek the informed consent of indigenous peoples before adopting decisions relating to their rights to land'. ${ }^{130}$ CERD has debated whether indigenous peoples' right to free and informed consent should grant them a right to veto decisions affecting their lands. ${ }^{131}$

Overall, despite the debates on whether indigenous peoples have a right to free and informed consent that could provide them with a right of veto, ${ }^{132}$ the practice of unilateral extinguishment appears to be in clear violation of the right of indigenous peoples to effective participation in decisions directly affecting them. In the near future, one could expect that international or regional courts would be asked to litigate on whether the practice of extinguishment is consistent with international legal standards on effective participation and consultation. Such litigation would be a welcome step that would shed light on the legality of extinguishment, which has been seen by many indigenous communities as one of the last vestiges of the legacy of colonization. For indigenous peoples, extinguishment is seen as an injustice that assumes the superiority of the colonial legacy over their own legal traditions. As Gèlè-Ahanhanzo, the Special Rapporteur on Contemporary Forms of Racism, Racial Discrimination, Xenophobia and Related Intolerance, pointed out in his report following his 2001 visit to Australia, extinguishment remains one of the issues which is altering the process of reconciliation with indigenous peoples. He concluded that indigenous peoples' consent in matters relat-

\footnotetext{
128 General Recommendation XXIII, Indigenous Peoples, UN Doc A/52/18, annex V, para 4(d) (1997).

129 ibid para 5.

130 Concluding observations of the Committee on the Elimination of Racial Discrimination, Australia, UN Doc CERD/C/AUS/CO/14, para 16

131 UN Doc CERD/C/SR.1235; on this issue, see P Thornberry (n 5) 217.

132 See Expanded working paper submitted by Mrs Antoanella-Iulia Motoc and the Tebtebba Foundation offering guidelines to govern the practice of Implementation of the principle of free, prior and informed consent of indigenous peoples in relation to development affecting their lands and natural resources, UN Doc E/CN.4/Sub.2/AC.4/2005/WP.1.
} 
ing to their land rights was a necessary component of reconciliation in Australia. ${ }^{133}$ This conclusion from the UN Special Rapporteur illustrates how crucial it is for national courts and international jurisdictions to examine the practice of extinguishment in the light of international standards on nondiscrimination and political participation. It is only based on such minimal human rights standards that courts would be able to sow the seeds of a sustainable process of reconciliation. As such the practice of extinguishment raises fundamental questions regarding the possibility of addressing past dispossession from a legal perspective. The recourse to extinguishment relies on the false idea that the past could simply be erased with some 'legal trick'.

\section{CONCLUSION}

Going back to the central question which was raised in the introduction to this article on whether the doctrine of indigenous title could serve as a potential model on the interaction between historical wrongs and contemporary indigenous peoples' land claims, it seems that the answer is not straightforward. By entrenching present-day indigenous peoples' land rights into their pre-existing customary systems of law, the doctrine builds a bridge between historical wrongs and the contemporary situation. To reconcile the past and the present, national jurisdictions have relied on the idea of traditions, as indigenous peoples have to prove that they have maintained a substantial traditional connection with their territories. However, this process of reconciliation also relies on the principle that only indigenous communities that are currently in occupation of the land would have their right to land recognized, for national courts limit their enquiries to present-day occupation. Thus, the indigenous title doctrine does inquire into the past in the name of reconciliation. However, in doing so it relies on a very scrupulous timing of the past as indigenous peoples have to prove first that they are maintaining a traditional cultural occupation of their lands, and secondly that this occupation has been continuous.

Hence, on a theoretical level, the common law approach to indigenous title seems to offer some functional and enforceable legal mechanisms on how to adjudicate such historical claims. However, on a more practical level, this bridge between the past and the present has been established on a controversial foundation through reference to the notion of 'extinguishment'. ${ }^{134}$ To resolve the historical nature of indigenous peoples' land rights, national courts have established that indigenous title is an extinguishable right. Even though the doctrine recognizes the pre-existence of indigenous customary laws, it

\footnotetext{
133 M Glèlè-Ahanhanzo, Special Rapporteur on contemporary forms of racism, racial discrimination, xenophobia and related intolerance, UN Doc E/CN.4/2002/24/Add 1 (26 Feb 2002).

134 Extinguishment is 'the cessation or cancellation of some right or interest'. Black's Law Dictionary (8th edn, Thomson West, St Paul, 2004) 623.
} 
does not expunge past dispossession, for it relies on the idea that once extinguished a land claim cannot be revived. As has been highlighted, the practice of extinguishment potentially clashes with international human rights norms on equality and political participation. Hence, while the doctrine brings some crucial advancement regarding indigenous peoples' land rights, such advancement is seriously undermined by the reference to extinguishment.

Nevertheless, despite this important limitation, the common law doctrine opens the door to another approach to the way we see law. Traditionally, law has been developed in a very insular way, and with the introduction of other customary systems of law in this normative system, the doctrine is totally reshaping that system. The introduction of customary indigenous laws relying on sources such as oral history or song will take time as overall it is an attempt to integrate into the common law a system of indigenous laws which rely on completely different sources of laws. As such, the common law doctrine certainly acts as a compelling model on how to accommodate national legislation and indigenous customary systems of laws. This movement towards the recognition of indigenous peoples' own customary systems of land tenure is an important step in the development of a legal theory on reconciliation. It shows that to reconcile past historical dispossession with the contemporary situation faced by indigenous peoples it is necessary to start by recognizing indigenous peoples' own systems of law.

Thus, despite all the limitations that were discussed throughout the article, the common law doctrine appears as one of the most elaborate legal discussions on the issue of reparation for past wrongs. As the common law doctrine illustrates, indigenous land-claim title raises fundamental issues about the legal repercussions of colonization, about the nature of State land, and about the extent to which it is permissible to distinguish between one group of people and another on ethnic grounds. Whereas this issue generates some significant political and societal choices, the message stemming from the national jurisdictions is that the issue of land restitution and land distribution between non-indigenous and indigenous populations is also a question of justice and not only one of politics. In many ways, the movement towards a comprehensive doctrine on indigenous title is part of what Slaughter has termed 'judicial globalization'. ${ }^{135}$ Indigenous peoples' land rights are an area of international law in constant development and in which there is a high level of interaction between national laws and international law. ${ }^{136}$ The rights that indigenous peoples have under international law are partly a product of landmark decisions taken at the national level. Each of these test cases contributes to what is a continuously evolving area of international law. The doctrine of indigenous title could serve as a potential model in the Commonwealth, but

135 A-M Slaughter, 'Judicial Globalization' (2000) 40 Va J Int'l L 1103.

$136 \mathrm{~S}$ Wiessner, 'Rights and Status of Indigenous Peoples: A Global Comparative and International Legal Analysis' (1999) 12 Har Hum Rts J 57. 
also in other legal systems. Moreover, the acknowledgment of the doctrine as a source of law by countries with a significant indigenous population such as Kenya, Botswana, Guyana or Malaysia could serve as a positive force in the movement towards the development of a stronger corpus of international law regarding indigenous peoples' land rights. As illustrated by the debates that led to the adoption of the UN Declaration on the Rights of Indigenous Peoples by the Human Rights Council, many initiatives are stopped because of States' reluctance to recognize indigenous peoples' historical rights over their lands. ${ }^{137}$ From this perspective it is certain that the expansion of the doctrine of indigenous title, which clearly recognizes the historical basis of indigenous peoples' right to land, could serve as an enlightening way to resolve the debate on the relationship between historical dispossession and contemporary land claims.

137 See J Gilbert, 'Indigenous Rights in the Making: The United Nations Declaration on the Rights of Indigenous Peoples' (2007) 14 IJMGR (forthcoming). 